\title{
SENSORY NERVE CONDUCTION VELOCITY IN MALNOURISHED CHILDREN
}

\author{
Md. Zabihullah'1, Dhirendra Kumar Agrawal2, Tabassum Shahab ${ }^{3}$
}

${ }^{1}$ Assistant Professor, Department of Physiology, GS Medical College and Hospital, Pilkhuwa, Hapur, Uttar Pradesh, India. ${ }^{2}$ Ex. Professor and Chairman, Department of Physiology, Jawaharlal Nehru Medial College and Hospital, Aligarh, Uttar Pradesh, India. ${ }^{3}$ Ex. Professor, Department of Paediatrics, Jawaharlal Nehru Medial College and Hospital, Aligarh, Uttar Pradesh, India.

\section{BACKGROUND}

ABSTRACT

Protein Energy Malnutrition (PEM) is the most widespread condition affecting the health of children in developing countries. Malnutrition in early childhood is characterized by nutritional deficiency at a crucial time in the development of the peripheral nerves. Nerve conduction studies can detect conduction changes in the peripheral nerves by measuring nerve conduction velocity. This study has been carried out to compare and analyse the Sensory Nerve Conduction Velocity (SNCV) between healthy controls and malnourished children.

\section{MATERIALS AND METHODS}

The present study was conducted on 60 children under five years of age with PEM who were divided into three age groups for statistical analysis: - Group 1: 01 year - 02 years, Group 2: > 02 years - 03 years, and Group 3: > 03 years - 04 years. Within each age group the patients were further divided into 2 groups on the basis of severity of malnutrition, first as suffering from mild-tomoderate malnutrition (grade 1 and 2 malnutrition) and second as suffering from severe malnutrition (grades 3 and 4 malnutrition). 45 healthy children ( $\mathrm{n}=15$ for each age group) without any nutritional problems served as control subjects. Assessment of nutritional status was done according to the guidelines of the Nutrition Subcommittee of the Indian Academy of Paediatrics. Nerve conduction study was performed on median, ulnar and sural nerves with neuroperfect EMG/NCV/EP System and SNCV was measured. One-Way ANOVA and Tukey-Kramer post-hoc test was applied to analyse the statistical significance of changes in the SNCV.

\section{RESULTS}

The SNCV was significantly reduced in children with severe malnutrition. No significant difference in SNCV was found in children with mild-to-moderate malnutrition.

\section{CONCLUSION}

The results of this study show significant reduction in SNCV in children with severe PEM which may be due to nutritional deficiency affecting myelination of peripheral nerves. Moreover, no significant difference in SNCV in children with mild to moderate PEM indicate an association between severity of malnutrition with changes in nerve conduction.

\section{KEY WORDS}

Malnutrition, Children, Sensory Nerve Conduction Velocity (SNCV).

HOW TO CITE THIS ARTICLE: Zabihullah M, Agrawal DK, Shahab T. Sensory nerve conduction velocity in malnourished children. J. Evolution Med. Dent. Sci. 2019;8(07):399-402, DOI: 10.14260/jemds/2019/88

\section{BACKGROUND}

The World Health Organization (WHO) defines malnutrition as "deficiencies, excesses or imbalances in a person's intake of energy and/or nutrients." 1 The present study, however, has dealt with the children suffering from Protein-Energy Malnutrition (PEM).

Malnutrition in children continues to be a scourge even in 21st century. The United Nations International Children's Emergency Fund (UNICEF) estimated that 150.8 million children under 5 years of age globally were stunted and 50.5 million wasted in 2017.2 Nearly half of all deaths in children under 5 are attributed to undernutrition. ${ }^{2}$

'Financial or Other Competing Interest': None.

Submission 21-01-2019, Peer Review 10-02-2019,

Acceptance 12-02-2019, Published 16-02-2019.

Corresponding Author:

Dr. Md. Zabihullah,

Flat No. 404, Teaching Staff Quarters,

GS Medical College,

Pilkhuwa, Hapur-245304,

Uttar Pradesh, India.

E-mail: drzabihullah81@gmail.com

DOI: $10.14260 /$ jemds $/ 2019 / 88$
As per the National Family Health Survey 2015-16 (NFHS4) estimates, $35.7 \%$ of Indian children under five years of age are underweight. ${ }^{3}$

Various studies on animals as well as on human beings have established an impact of malnutrition on neurochemistry, structure and function of brain.4-7 Malnutrition in early childhood is characterized by nutritional deficiency at a crucial time in the development of the central nervous system when malnutrition presents a higher risk. In humans, the critical period extends from the third month of pregnancy to 2 years of age. ${ }^{8}$ Peripheral nerve myelination also occurs during this period. It begins about the 15 th week of gestation ${ }^{9}$ and continues throughout the first 2 to 5 years of life ${ }^{10-11}$ and this process may be affected by malnourishment in children.

The loss of myelin may delay or block conduction in the demyelinated axons. Nerve conduction tests can detect slowed conduction in peripheral nerves by measuring nerve conduction velocity. Delayed Motor Nerve Conduction Velocity (MNCV) in malnourished children has been shown by various studies.12-14 However, data regarding Sensory Nerve Conduction Velocity (SNCV) in malnourished children are very limited. 


\section{MATERIALS AND METHODS}

The present case control study was conducted in Neurophysiology Laboratory, Department of Physiology, Jawaharlal Nehru Medical College and Hospital (JNMCH), Aligarh Muslim University (AMU), Aligarh. Institutional Ethical Committee approval was obtained before commencing the study. A written and informed consent was obtained from parents/guardian of all the patients and control subjects prior to the test. Study sample consisted of 60 children under five years of age with protein energy malnutrition (PEM) attending the Outpatient Department (OPD) or admitted to the Inpatient Department (IPD) of the Department of Paediatrics, JNMCH, AMU, Aligarh. 45 healthy children under five years of age without any nutritional problem attending the Paediatrics OPD for ambulatory checkup served as control subjects. The sample size estimation was done at convenience. Assessment of nutritional status was done according to the guidelines of the Nutrition Subcommittee of the Indian Academy of Paediatrics. ${ }^{15}$

SNCV study was performed on median, ulnar and sural nerves with Neuroperfect EMG/NCV/EP System. Sensory nerve action potential was recorded antidromically using ring electrodes. The distance between the recording electrode \& the stimulation site was measured. SNCV was measured by dividing the distance between the stimulating and recording sites by the latency. 16

Statistical Package for Social Science (SPSS 17.0) software was used for the statistical analysis. One-Way ANOVA and Tukey-Kramer post-hoc test were applied to analyse the statistical significance of changes in the SNCV. P value of less than 0.05 was taken as statistically significant.

\section{RESULTS}

Since nerve conduction velocity varies with age, ${ }^{17}$ children were divided into three age groups for statistical analysis: Group 1: 01 year - 02 years, Group 2: > 02 years - 03 years, and Group 3: $>03$ years -04 years. Within each age group the patients were further divided into 2 groups on the basis of severity of malnutrition, first as suffering from mild-tomoderate malnutrition (grade 1 and 2 malnutrition) and second as suffering from severe malnutrition (grades 3 and 4 malnutrition).

\begin{tabular}{|c|c|c|c|c|c|c|c|}
\hline \multirow{2}{*}{ Groups } & \multirow{2}{*}{$\begin{array}{c}\text { Age } \\
\text { (Years) }\end{array}$} & \multicolumn{2}{c|}{$\begin{array}{c}\text { Sex } \\
\text { (Controls) }\end{array}$} & \multicolumn{2}{c|}{$\begin{array}{c}\text { Sex } \\
\text { (PEM 1 \& 2) }\end{array}$} & \multicolumn{2}{c|}{$\begin{array}{c}\text { Sex } \\
\text { (PEM 3 \& 4) }\end{array}$} \\
\cline { 2 - 8 } & & Male & Female & Male & Female & Male & Female \\
\hline Group 1 & $01-02$ & 9 & 6 & 7 & 5 & 5 & 7 \\
\hline Group 2 & $>02-03$ & 9 & 6 & 6 & 4 & 6 & 3 \\
\hline Group 3 & $>03-04$ & 9 & 6 & 5 & 4 & 5 & 3 \\
\hline \multicolumn{7}{|c|}{ Table 1. Age and Sex Distribution of Controls and Cases } \\
\hline \multicolumn{7}{|c|}{ PEM Protein Energy Malnutrition } \\
\hline
\end{tabular}

\begin{tabular}{|c|c|c|c|c|c|}
\hline Age Groups & Control & $\begin{array}{c}\text { PEM Grade } \\
\mathbf{( 1 ~ \& ~ 2 )}\end{array}$ & $\begin{array}{c}\text { PEM Grade } \\
\mathbf{( 3 ~ \& ~ 4 )}\end{array}$ & p-Value & $\begin{array}{c}\text { Statistical } \\
\text { Significance }\end{array}$ \\
\hline Group 1 & $44.97 \pm 1.89$ & $43.93 \pm 1.07$ & $38.34 \pm 1.55$ & $<0.001$ & Significant \\
\hline Group 2 & $47.97 \pm 1.85$ & $47.08 \pm 1.94$ & $41.73 \pm 1.34$ & $<0.001$ & Significant \\
\hline Group 3 & $49.67 \pm 1.81$ & $48.45 \pm 1.76$ & $41.87 \pm 1.67$ & $<0.001$ & Significant \\
\hline
\end{tabular}

Table 2a. One-Way ANOVA Comparing Mean SNCV (m/s) of Ulnar Nerve Between Control Group and Two Groups of Cases (PEM Grade 1 \& 2 and PEM Grade 3 \& 4) in Three Age Groups

SNCV= Sensory Nerve Conduction Velocity, PEM= Protein Energy Malnutrition

\begin{tabular}{|c|c|c|c|c|c|}
\hline $\begin{array}{c}\text { Age } \\
\text { Groups }\end{array}$ & Control & $\begin{array}{c}\text { PEM Grade } \\
\text { (1 \& 2) }\end{array}$ & $\begin{array}{c}\text { PEM Grade } \\
\text { (3 \& 4) }\end{array}$ & p-Value & $\begin{array}{c}\text { Statistical } \\
\text { Significance }\end{array}$ \\
\hline Group 1 & $45.68 \pm 1.85$ & $44.65 \pm 1.29$ & $39.44 \pm 1.53$ & $<0.001$ & Significant \\
\hline Group 2 & $48.06 \pm 2.01$ & $47.00 \pm 1.96$ & $41.73 \pm 1.39$ & $<0.001$ & Significant \\
\hline Group 3 & $49.98 \pm 2.16$ & $49.14 \pm 1.49$ & $42.33 \pm 1.71$ & $<0.001$ & Significant \\
\hline \multicolumn{7}{|r|}{ Table 2b. One-Way ANOVA Comparing Mean SNCV (m/s) of Median Nerve Between Control Group and Two } \\
Groups of Cases (PEM Grade 1 \& 2 and PEM Grade 3 \& 4) in Three Age Groups \\
\hline
\end{tabular}

\begin{tabular}{|c|c|c|c|c|c|}
\hline $\begin{array}{c}\text { Age } \\
\text { Groups }\end{array}$ & Control & $\begin{array}{c}\text { PEM Grade } \\
\mathbf{( 1 ~ \& ~ 2 )}\end{array}$ & $\begin{array}{c}\text { PEM Grade } \\
\mathbf{( 3 ~ \& ~ 4 )}\end{array}$ & p-Value & $\begin{array}{c}\text { Statistical } \\
\text { Significance }\end{array}$ \\
\hline Group 1 & $47.91 \pm 2.02$ & $46.63 \pm 1.58$ & $39.54 \pm 2.20$ & $<0.001$ & Significant \\
\hline Group 2 & $50.58 \pm 2.41$ & $48.59 \pm 2.90$ & $42.06 \pm 2.32$ & $<0.001$ & Significant \\
\hline Group 3 & $51.60 \pm 2.00$ & $50.12 \pm 1.63$ & $42.56 \pm 1.45$ & $<0.001$ & Significant \\
\hline Table 2c. One-Way ANOVA Comparing Mean SNCV (m/s) of Sural Nerve Between Control Group and Two Groups \\
of Cases (PEM Grade 1 \& 2 and PEM Grade 3 \& 4) in Three Age Groups \\
SNCV= Sensory Nerve Conduction Velocity, PEM= Protein Energy Malnutrition \\
\hline
\end{tabular}




\begin{tabular}{|c|c|c|c|c|}
\hline \multirow{3}{*}{ Age Groups } & \multirow{3}{*}{ Groups Compared } & \multicolumn{3}{|c|}{ Dependent Variable } \\
\cline { 2 - 5 } & & SNCV Ulnar Nerve & SNCV Median Nerve & SNCV Sural Nerve \\
\cline { 2 - 4 } & & p Value & p Value & p Value \\
\hline \multirow{3}{*}{ Group 1 } & Control- PEM Grade (1 \& 2) & $0.215^{*}$ & $0.232^{*}$ & $0.225^{*}$ \\
\cline { 2 - 5 } & Control- PEM Grade (3 \& 4) & $<0.001^{\dagger}$ & $<0.001^{\dagger}$ & $<0.001^{\dagger}$ \\
\cline { 2 - 5 } & PEM Grade (1 \& 2)- PEM Grade (3 \& 4) & $<0.001^{\dagger}$ & $<0.001^{\dagger}$ & $<0.001^{\dagger}$ \\
\hline \multirow{3}{*}{ Group 2 } & Control- PEM Grade (1 \& 2) & $0.436^{*}$ & $0.354^{*}$ & $<.151^{*}$ \\
\cline { 2 - 5 } & Control- PEM Grade (3 \& 4) & $<0.001^{\dagger}$ & $<0.001^{\dagger}$ & $<0.001^{\dagger}$ \\
\cline { 2 - 5 } & PEM Grade (1 \& 2)- PEM Grade (3 \& 4) & $<0.001^{\dagger}$ & $<0.001^{\dagger}$ & $.136^{*}$ \\
\hline \multirow{3}{*}{ Group 3 } & Control- PEM Grade (1\&2) & $0.245^{*}$ & $0.552^{*}$ & $<0.001^{\dagger}$ \\
\cline { 2 - 5 } & Control- PEM Grade (3 \& 4) & $<0.001^{\dagger}$ & $<0.001^{\dagger}$ & $<0.001^{\dagger}$ \\
\cline { 2 - 5 } & PEM Grade (1 \& 2)-PEM Grade (3 \& 4) & $<0.001^{\dagger}$ & $<0.001^{\dagger}$ & \\
\hline
\end{tabular}

Table 3. Post Hoc Analysis Showing Multiple Comparisons of Mean SNCV (m/s) of Ulnar Nerve, Median Nerve and Sural Nerve Between Three Children Groups (Control, PEM Grade 1 \& 2 and PEM Grade 3 \& 4) in Three Age Groups. (Tukey-Kramer Test)

* Not Significant, † Significant, SNCV= Sensory Nerve Conduction Velocity, PEM= Protein Energy Malnutrition

Results of statistical are presented in tables $2 \mathrm{a}, 2 \mathrm{~b}, 2 \mathrm{c}$ and 3. In one-way ANOVA test, comparison of mean SNCV of Ulnar nerve, Median nerve and Sural nerve between control Group and two groups of cases (PEM Grade 1\&2 and PEM Grade $3 \&$ 4) was statistically significant $(\mathrm{P}<0.05)$ in all the three age groups. In Post Hoc Tukey - Kramer test, comparison of mean SNCV of all 3 nerves in PEM Grade 3\&4 group with that of control group was statistically significant $(\mathrm{P}<0.05)$ in all the three age groups. However, comparison of mean SNCV of all 3 nerves in PEM Grade 1\&2 group with that of control group was not statistically significant $(\mathrm{P}>0.05)$ in all the three age groups.

\section{DISCUSSION}

Myelination, diameter of the nerve fibre, and internodal differences are the determinants of nerve Conduction velocity. ${ }^{18}$ Myelination of peripheral nervous system begins during the fourth month of foetal life and gets completed at around 5 years of age. ${ }^{19}$ The axons also mature during the prenatal and postnatal periods, beginning at 20 weeks' gestation and reaching a maximum between ages 2 and 5 years. ${ }^{20} \mathrm{~A}$ direct relationship exists between the diameter of the nerve fibre and the thickness of the myelin sheath. The nodes of Ranvier are also remodelled during maturation and the maximum internodal distances occur at 5 years of age. ${ }^{21}$ Malnutrition in children under five years of age may affect this ongoing maturation of peripheral nerves in children.

Chopra et $\mathrm{al}^{22}$ studied biopsies of sural nerve which is a sensory nerve of lower limb, from children with mild to moderate malnutrition as well as with severe malnutrition. The normal developmental pattern for myelinated fibre size distribution was impaired with a persistence of small myelinated fibres, and there was a failure of internodal segments on large fibres to elongate with increase in age in children with severe PEM. Moreover, they reported significant segmental demyelination in about 50 per cent of children with severe PEM. In contrast sural nerve biopsies from children with mild to moderate PEM were characterized by a normal developmental change in myelinated fibres with an increasing proportion of medium and large size fibres, and an appropriate relationship of internodal length to fibre diameter. Evidence of mild segmental demyelination was found in only one child with mild to moderate PEM.

Our study has shown significant reduction in SNCV in children with severe PEM while no significant difference in SNCV was found in children with mild to moderate PEM. The results were similar in all age groups ranging from 1 year to 4 years. Electrophysiological findings in children with PEM revealing impairment of peripheral nerve function involving sensory fibres has been reported earlier. ${ }^{22}$ Rubha $S$ et al ${ }^{23}$ has reported significant reduction in median nerve SNCV in malnourished children.

As discussed previously, PEM in children under five years of age can retard the process of myelination in peripheral nerves. This might be the causative factor for significant reduction in SNCV in children with severe PEM.

\section{CONCLUSION}

This study shows significant reduction in SNCV in children with severe PEM while no significant difference in SNCV was found in children with mild to moderate PEM. These results indicate an association between severity of malnutrition with changes in nerve conduction. Nutritional deficiency affecting myelination of peripheral nerves might be the cause for significantly decreased sensory nerve conduction velocity in severely malnourished children, but whether these changes in nerve conduction can be reversed or not by nutritional rehabilitation needs to be evaluated by further studies.

\section{REFERENCES}

[1] World Health Organization. Health topics. Malnutrition. Accessed 12 January 2019 https://www.who.int/topics/malnutrition/en/

[2] UNICEF: UNICEF data: monitoring the situation of children and women. Accessed 12 January 2019. https://data.unicef.org/topic/nutrition/malnutrition/

[3] International Institute of Population Sciences and ORC Macro. NFHS-4. India fact sheet. Accessed 12 January 2019. http://rchiips.org/nfhs/factsheet_nfhs-4.shtml

[4] El-Sherif AM, Babrs GM, Ismail AM. Cranial, magnetic resonance imaging (MRI) changes in severely malnourished children before and after treatment. Life Science J 2012;9(3):738-42.

[5] Miranda M, Nóbrega FJ, Sato K, et al. Neuropsychology and malnutrition: a study with 7 to 10 years-old children in a poor community. Rev Bras Saúde Matern Infant 2007;7(1):45-54.

[6] Cordero ME, Valenzuela CY, Rodriguez A, et al. Dendritic morphology and orientation of pyramidal cells of the neocortex in two groups of early postnatal undernourished-rehabilitated rats. Brain Res. Dev. Brain Res 2003;142(1): 37-45. 
[7] Dobbing J, Widdowson SM. The effect of undernutrition and subsequent rehabilitation on myelination of rat brain as measured by its composition. Brain 1965;88(2):357-68.

[8] Morgane PJ, Austin-LaFrance R, Bronzino J, et al. Prenatal malnutrition and development of the brain Neurosci Biobehav Rev 1993;17(1):91-128.

[9] Gamble HJ, Breathnach AS. An electron-microscope study of human foetal peripheral nerves. J Anat 1965;99(Pt 3):573-84.

[10] Cottrell L. Histologic variations with age in apparently normal peripheral nerve trunks. Arch Neurol 1940;43(6):1138-50.

[11] Rexed B. Contribution to knowledge of postnatal development of peripheral nervous system in man: study of bases and scope of systematic investigations into fibre size in peripheral nerves. Acta Psychiatry Neurol Scand Suppl 1944;33:1-206.

[12] Ghosh S, Vaid K, Mohan M, et al. Effect of degree and duration of protein energy malnutrition on peripheral nerves in children. J Neurol Neurosurg Psychiatry 1979;42(8):760-3.

[13] Kumar A, Ghai OP, Singh N, et al. Delayed nerve conduction velocities in children with protein-calorie malnutrition. Journal of Pediatrics 1977;90(1):149-53.

[14] Singh N, Kumar A, Ghai OP. Conduction velocity of motor nerves in children suffering from proteincalorie malnutrition and marasmus. Electromyogr Clin Neurophysiol 1976;16(4):381-92.

[15] Shah PM. Nutrition subcommittee of the Indian academy of pediatrics. Indian Pediatrics 1972;9:360.
[16] Misra UK, Kalita J. Principles of nerve conduction velocity. In: Clinical neurophysiology. $3^{\text {rd }}$ edn. New Delhi: Elsevier India 2014:21-9.

[17] Garcia A, Calleja J, Antolin FM, et al. Peripheral motor and sensory nerve conduction studies in normal infants and children. Clin Neurophysiol 2000;111(3):513-20.

[18] Barrett KE, Barman SM, Boitano S, et al. Excitable tissue: nerve. In: Ganong's review of medical physiology. $25^{\text {th }}$ edn. New Delhi: McGraw-Hill 2016:85-98.

[19] Webster HF, Favilla JT. Development of peripheral nerve fibers. In: Dyck PJ, Thomas PK, Lambert EH, et al, eds. Peripheral neuropathy. Vol. 1. $2^{\text {nd }}$ edn. Philadelphia: WB Saunders 1984:329-59.

[20] Thomas JE, Lambert EH. Ulnar nerve conduction velocity and H-reflex in infants and children. J Appl Physiol 1960;15:1-9.

[21] Gutrecht JA, Dyck PJ. Quantitative teased-fiber and histologic studies of human sural nerve during postnatal development. J Comp Neurol 1970;138(1):117-29.

[22] Chopra JS, Dhand UK, Mehta S, et al. Effect of protein calorie malnutrition on peripheral nerves. A clinical, electrophysiological and histopathological study. Brain 1986;109(Pt 2):307-23.

[23] Rubha S, Vinodha R. Effects of protein energy malnutrition on peripheral nerve conduction in children. Int J Med Res Health Sci 2015;4(4):768-70. 